\title{
Isolation of Human Eosinophil Phospholipase D
}

\author{
Laurence A. Kater, $†$ Edward J. Goetzl, and K. Frank Austen \\ From the Departments of Medicine, Harvard Medical School and Robert B. \\ Brigham Hospital, Boston, Massachusetts 02120
}

\begin{abstract}
A в S T R A C T Phospholipase D preferentially contained in human eosinophil polymorphonuclear leukocytes as compared to other leukocytes was isolated by sequential anion and cation exchange chromatography and gel filtration. The purified eosinophil enzyme specifically liberated choline from $L$ - $\alpha$-phosphatidyl choline with a $\mathrm{pH}$ optimum of 4.5-6.0 and exhibited a $\mathrm{pI}$ of $5.8-6.2$ on polyacrylamide-gel isoelectric focusing, which are properties shared by phospholipase D from plant sources; however, its apparent mol wt of 60,000 is approximately one-half that of the plant enzymes. Eosinophil and cabbage phospholipase $\mathrm{D}$ inactivated a partially purified rat platelet-activating factor (PAF) in a time- and dosedependent reaction. The cleavage of this PAF activity was attributed to the inherent phospholipase D activity of the eosinophil enzyme since the two activities chromatographed together at each purification step, and there was apparent reciprocal inhibition of choline-generating activity by PAF and of PAF-inactivating activity by phosphatidyl choline. Thus, possible regulatory functions of the eosinophil in immediate hypersensitivity reactions include inactivation of a PAF by phospholipase $\mathrm{D}$ as well as degradation of slow-reacting substance of anaphylaxis by arylsulfatase $B$.
\end{abstract}

\section{INTRODUCTION}

Mixed leukocytes from actively sensitized rabbits interact with specific antigen to release a soluble factor, platelet-activating factor (PAF), ${ }^{1}$ which causes the

† This study represents in part the investigations into the cellular regulation of the inflammatory response by $\mathrm{Dr}$. Laurence A. Kater, whose untimely death occurred during a fellowship supported by the National Institutes of Health (AM-05076), in the Departments of Medicine, Harvard Medical School and Robert B. Brigham Hospital, Boston, Mass.

Dr. Goetzl is an investigator of the Howard Hughes Medical Institute.

Received for publication 6 October 1975 and in revised form 29 December 1975.

${ }_{1}$ Abbreviations used in this paper: $\mathrm{PAF}$, platelet-activating factor; SPB, standard platelet buffer; SRS-A, slow reacting substance of anaphylaxis. secretion of amines from normal rabbit platelets (1-4). The basophil polymorphonuclear leukocyte sensitized with $\operatorname{IgE}$ is the source of PAF $(4,5)$. PAF activities were also derived by prolonged incubation of rabbit or human mixed peripheral leukocytes in alkaline buffer (6), by addition of the calcium ionophore A23187 to human leukemic basophils (7), and by IgE-dependent reactions in human leukocyte suspensions (6) and lung tissue fragments (8). PAF obtained from rabbit or mixed human leukocytes incubated in alkaline buffer exhibited cationic characteristics on ion-exchange chromatography, filtered with an apparent mol wt of 1,100 on Sephadex LH-20, and chromatographed on silica thinlayer plates in a region staining for phospholipid (9).

To obtain quantities of a PAF activity sufficient for purification and characterization of its enzymatic susceptibility, the activity was generated in the peritoneal cavity of rats prepared with hyperimmune rat antiserum and challenged with specific antigen (10). The PAF activity generated exhibited an apparent mol wt of $300-500$, and was susceptible to inactivation by cabbage phospholipase $\mathrm{D}$, but not by phospholipases $\mathrm{A}$ and $\mathrm{B}$ or mild base hydrolysis (11). Since the eosinophil polymorphonuclear leukocyte has the capacity to inactivate other mediators of immediate-type hypersensitivity reactions (12), eosinophils were examined as a source of phospholipase $\mathrm{D}$ capable of destroying this PAF activity.

\section{METHODS}

Phospholipases A and B, pronase, and subtilisin (Calbiochem, Los Angeles, Calif.), phospholipases C (Clostridium welchii) and D (cabbage), L- $\alpha$-phosphatidyl choline, limpet arylsulfatase, and choline iodide (Sigma Chemical Co., St. Louis, Mo.), human serum albumin and ovalbumin (Miles Laboratories, Inc., Elkhart, Ind.), heparin (sodium heparin injection, USP, Upjohn Co., Kalamazoo, Mich.), Sephadex, Blue dextran, and Ficoll (Pharmacia Fine Chemicals, Piscataway, N. J.), dihexanoyl L- $\alpha$-lecithin (Supelco, Inc., Bellefonte, $\mathrm{Pa}$.), silica gel $\mathrm{G}$ thin-layer plates (Brinkmann Instruments, Inc., Westbury, N. Y.), 2',7'-dichlorofluorescein spray (EM Laboratories, Inc., Elmsford, N. Y.), phosphatidic acid (Grand Island Biological Co., Grand Island, N. Y.) $\left[2-{ }^{14} \mathrm{C}(\mathrm{N})\right] 5$-hydroxytryptamine binoxalate $\left(\left[{ }^{14} \mathrm{C}\right]-\right.$ serotonin) and Aquasol Universal LSC Cocktail (New 
England Nuclear Corp., Boston, Mass.), Amberlite XAD-2 (100-200 mesh) and silicic acid (Mallinckrodt Inc., St. Louis, Mo.), diethylaminoethyl cellulose (DE-52) and carboxymethyl cellulose (CM-52) (Whatman Chemicals, Div. W \& R Balston, Maidstone, Kent, England), ampholytes (Ampholine, LKB Instruments, Inc., Rockville, Md.), and sodium lauryl sulfate and silicone coating (Dricote) (Fisher Scientific Co., Pittsburgh, Pa.) were obtained as noted. Plastic or siliconized glass was used in the processing of platelets and leukocytes and in all column chromatography. Rat antiovalbumin rich in IgGa was prepared by immunizing Wistar rats as previously described (10). Isoelectric focusing was performed at $4^{\circ} \mathrm{C}$ and $600 \mathrm{~V}$ in $4 \%$ polyacrylamide gels containing ampholytes with a range from $\mathrm{pH} 4$ to 10 . The ampholytes were prefocused at a constant $600 \mathrm{~V}$ to achieve a current of 3.0 mamps, and then focused for an additional $4 \mathrm{~h}$ after application of the sample in a gel electrophoresis apparatus (Metaloglass Co., Boston, Mass.).

Assay, generation, and purification of $P A F$ activity. PAF was assayed by its capacity to release $\left[{ }^{14} \mathrm{C}\right]$ serotonin from labeled human platelets. Platelet-rich plasma from normal human volunteers, who had not ingested drugs known to affect platelet function for at least 5 days before their blood was drawn, was prepared by centrifuging citrate anticoagulated blood at $100 \mathrm{~g}$ for $15 \mathrm{~min}$ at room temperature to yield a pellet of erythrocytes and leukocytes. The platelets were then sedimented at $800 \mathrm{~g}$ for $15 \mathrm{~min}$ at room temperature. The platelet pellet was washed once in a standard $\mathrm{pH}$ 7.2 platelet buffer (SPB) containing $0.004 \mathrm{M} \mathrm{KH}_{2} \mathrm{PO}_{4}$, $0.006 \mathrm{M} \mathrm{Na}_{2} \mathrm{HPO}_{4}, 0.1 \mathrm{M} \mathrm{NaCl}, 0.1 \%$ glucose, and $0.1 \%$ human serum albumin (13) made $10 \%$ ( vol/vol) in citrate anticoagulant (citric acid $0.076 \mathrm{M}$, sodium citrate $0.15 \mathrm{M}$, $\mathrm{pH}$ 5.2.). The platelets which contained less than $0.1 \%$ leukocytes as assessed by phase contrast microscopy, were suspended in SPB with citrate to a concentration of 1-2 $\times$ $10^{10}$ platelets $/ \mathrm{ml}$, and incubated with $8 \mu \mathrm{Ci}\left[{ }^{14} \mathrm{C}\right]$ serotonin for $30 \mathrm{~min}$ at $37^{\circ} \mathrm{C}$. The labeled platelets were washed once in SPB with citrate, and then resuspended at a concentration of $3-5 \times 10^{8}$ platelets $/ \mathrm{ml}$ in SPB with $1 \times 10^{-3}$ $\mathrm{M} \mathrm{CaCl}_{2}\left(\mathrm{SPB}^{++}\right) .250 \mu \mathrm{l}$ of labeled platelets in $10 \times 75-\mathrm{mm}$ tubes were incubated with $100 \mu$ l of reference or unknown materials at $37^{\circ} \mathrm{C}$ for $30 \mathrm{~min} .500 \mu \mathrm{l}$ of $\mathrm{SPB}^{++}$was added to each tube, the cells were sedimented at $800 \mathrm{~g}$ for 15 min, and the supernates were decanted into glass scintillation vials. The cell pellets were solubilized in $500 \mu \mathrm{l}$ of $3 \%$ ( vol/vol) sodium lauryl sulfate with incubation at $37^{\circ} \mathrm{C}$ for $15 \mathrm{~min}$ and then transferred to scintillation vials. The solubilized pellets and supernates were counted in $10 \mathrm{ml}$ of scintillant in a Nuclear Chicago Mark I Scintillation counter (Nuclear Chicago Corp., Des Plaines, Ill.). The percent release of $\left[{ }^{14} \mathrm{C}\right]$ serotonin was calculated by dividing the counts per minute of the supernate by the counts per minute of the pellet plus supernate and multiplying by 100 . Spontaneous release of $\left[{ }^{14} \mathrm{C}\right]$ serotonin varied from 8 to $12 \%$. Net percent release was calculated by subtracting spontaneous percent release from that occurring in response to a specific stimulus. The net percent release achieved with untreated PAF activity minus the net percent release with treated PAF, divided by the net percent release with untreated PAF times 100 was used to express percent PAF inactivation.

Wistar rats were prepared by intraperitoneal injection of $1 \mathrm{ml}$ of hyperimmune rat antiovalbumin antiserum, and after $2 \mathrm{~h}$ were challenged intraperitoneally with $2 \mathrm{mg}$ of ovalbumin in $5 \mathrm{ml}$ Tyrode's solution containing $0.1 \mathrm{~g} / 100 \mathrm{ml}$ human serum albumin and heparin $(50 \mathrm{U} / \mathrm{ml}) .5 \mathrm{~min}$ later the animals were sacrificed, the peritoneal fluids were harvested and pooled, and $50-\mathrm{ml}$ portions were centrifuged at $100 \mathrm{~g}$ for $15 \mathrm{~min}$ at $4^{\circ} \mathrm{C}$. The supernate was deproteinated by the addition of $4 \mathrm{vol}$ of absolute ethanol and centrifuged at $10,000 \mathrm{~g}$ for $15 \mathrm{~min}$ at $4^{\circ} \mathrm{C}$, evaporated to dryness in a rotary evaporator under vacuum (Buchler Instruments, Fort Lee, N. J.), and resuspended in $1.8 \mathrm{ml}$ distilled water. The suspension was incubated with $0.2 \mathrm{ml} 1 \mathrm{~N} \mathrm{NaOH}$ at $37^{\circ} \mathrm{C}$ for $30 \mathrm{~min}$ and $1.8 \mathrm{ml}$ applied to a $0.9 \times 30-\mathrm{cm}$ column of Amberlite XAD-2. The column was eluted with $30 \mathrm{ml}$ of distilled water, and then with $30 \mathrm{ml}$ of $80 \%$ ethanol in water. The $80 \%$ ethanol eluate, containing the bulk of PAF activity, was evaporated to dryness, resuspended in $2.0 \mathrm{ml}$ of $100 \%$ ethanol, and applied to a $0.9 \times 30-\mathrm{cm}$ column of silicic acid. The column was sequentially eluted with $30-\mathrm{ml}$ portions of hexane, methylene chloride, acetone, $n$-propanol, and ethanol: ammonium hydroxide: water $(6: 3: 1 \mathrm{vol} / \mathrm{vol})$ (14). The fractions were evaporated to dryness and resuspended in $2.0 \mathrm{ml}$ of $\mathrm{SPB}^{++}$(13) for assay of their platelet-activating activity. The PAF activity was present only in the ethanol: ammonia: water eluate.

In a comparable isolation procedure the ethanol:ammonia : water fraction from the silicic acid step was lyophilized and resuspended in $2 \mathrm{ml}$ of $80 \%$ ethanol and applied to a $1.5 \times 70-\mathrm{cm}$ column of Sephadex LH-20. The column was equilibrated and developed with $80 \%$ ethanol in water. $100-\mu 1$ portions of each $2.2 \mathrm{ml}$ fraction were assayed for PAF activity and for slow reacting substance of anaphylaxis (SRS-A) by diluting the portions in the appropriate buffer for each assay (Fig. 1). PAF activity filtered as a single peak with an apparent mol wt of 300-500, presenting within a region which also contained SRS-A. The capacity of the rat $\mathrm{PAF}$ activity purified through silicic acid to release radiolabeled serotonin from human platelets exhibited a steep dose-response in the range of $0-40 \%$ net release with PAF at dilutions of $1: 1,000$ to $1: 100$ and all assays of PAF activity utilized dilutions in this range (Fig. 2).

Preparation of cell extracts as a source of phospholipase $D$. Blood from normal subjects and patients with peripheral blood hypereosinophilia was drawn into citrate anticoagulant with or without $1 \mathrm{~g} / 100 \mathrm{ml}$ of dextran (13). The tubes with dextran were incubated for $45 \mathrm{~min}$ at $37^{\circ} \mathrm{C}$ to allow erythrocyte sedimentation; the supernatant leukocyte-rich plasma was aspirated and centrifuged at $100 \mathrm{~g}$ for $15 \mathrm{~min}$ at room temperature to yield a pellet of mixed leukocytes. This preparation obtained from eosinophil-rich donors was the source of eosinophils and that obtained from normal donors served as a source of polymorphonuclear and mononuclear leukocytes for fractionation on cushions of HypaqueFicoll (16). Blood harvested without dextran was spun at $100 \mathrm{~g}$ for $15 \mathrm{~min}$ at room temperature; the supernate was aspirated as a source of platelets and the lower layer of the cone of packed cells was utilized as a source of erythrocytes. The platelets were then sedimented at $800 \mathrm{~g}$ for 15 min at room temperature. Each cell preparation was washed twice and suspended in $\mathrm{SPB}^{++}$. A sample was taken to determine total cell count and differential, and the remaining cells were frozen and thawed three times and sonicated on ice (Ultrasonic Instruments, Inc., Farmingdale, N. Y.) in 30-s bursts for a total of $5 \mathrm{~min}$.

Phospholipase $D$ assay. Phospholipase D of cabbage origin or present in eosinophil extracts and their chromatographic fractions was assayed by its ability to cleave choline from L- $\alpha$-phosphatidyl choline; choline was quantitated by formation and colorimetric detection of choline enneaiodide (15). $\frac{1}{10} \mathrm{ml}$ of enzyme source was mixed with $0.1 \mathrm{ml}$ of $0.1 \mathrm{M}$ acetate buffer, $\mathrm{pH} 5.5$ containing $1 \mathrm{mM} \mathrm{CaCl} 2$; and 


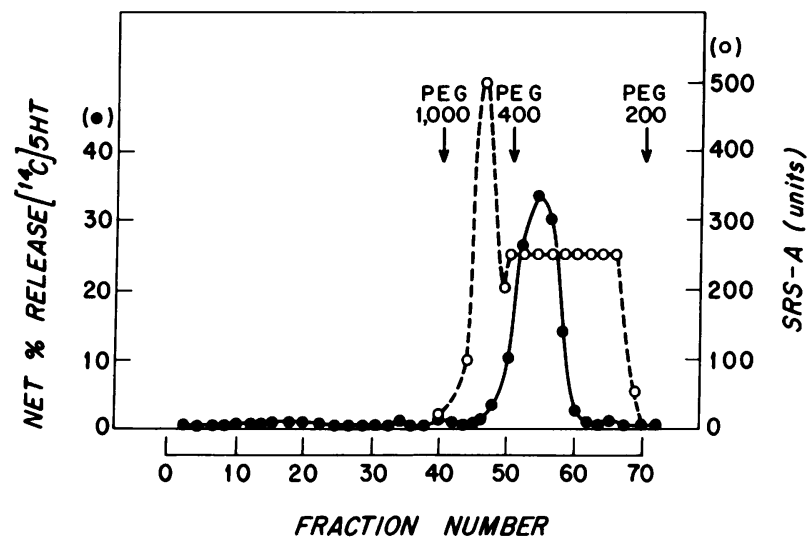

Figure 1 Sephadex LH-20 chromatography of PAF. The pooled and concentrated ethanol:ammonia: water fraction from the silicic acid step was applied to a column of bed volume $124 \mathrm{ml}$ which was run at a flow rate of $6 \mathrm{ml} / \mathrm{h}$. Fractions of $2.2 \mathrm{ml}$ were collected and $100-\mu 1$ portions of each fraction were assayed in duplicate for each mediator. PEG, polyethylene glycol.

$0.1 \mathrm{ml}$ of $4 \mathrm{mM} \mathrm{L- \alpha}$-phosphatidyl choline in $100 \%$ ethanol was then added. The mixture was incubated at $37^{\circ} \mathrm{C}$ for $1 \mathrm{~h}$. The reaction was stopped by the addition of $1 \mathrm{ml}$ $\mathrm{CHCl}_{3}$-methanol $(2: 1, \mathrm{vol} / \mathrm{vol})$, and the chloroform-rich lower phase containing unreacted substrate was aspirated and discarded. The upper phase was extracted twice with 1 $\mathrm{ml} \mathrm{CHCl}_{3}$-methanol $(17: 3, \mathrm{vol} / \mathrm{vol})$ and the lower phase discarded each time. The upper phase was heated at $70^{\circ} \mathrm{C}$ for $30 \mathrm{~min}$ to evaporate organic solvents, cooled to room temperature, and developed with $0.1 \mathrm{ml}$ of $25 \%$ (wt/vol) trichloroacetic acid containing $0.025 \mu \mathrm{mol}$ of choline iodide and $0.2 \mathrm{ml}$ of iodine reagent $\left(15.6 \mathrm{~g}\right.$ of $\mathrm{I}_{2}$ and $20 \mathrm{~g}$ of $\mathrm{KI} / 100 \mathrm{ml}$ water). The reaction mixtures were placed at $4^{\circ} \mathrm{C}$ for $30 \mathrm{~min}$ for formation of the choline enneaiodide precipitate. After centrifugation at $1,000 \mathrm{~g}$ for $15 \mathrm{~min}$ at $4^{\circ} \mathrm{C}$ the supernate was aspirated and discarded. The precipitate was washed with cold distilled water, dissolved in 1 $\mathrm{ml}$ of $\mathrm{CHCl}_{3}$ with mechanical agitation, and further diluted with $4 \mathrm{ml} \mathrm{CHCl}_{3}$. Mixtures for a standard curve were

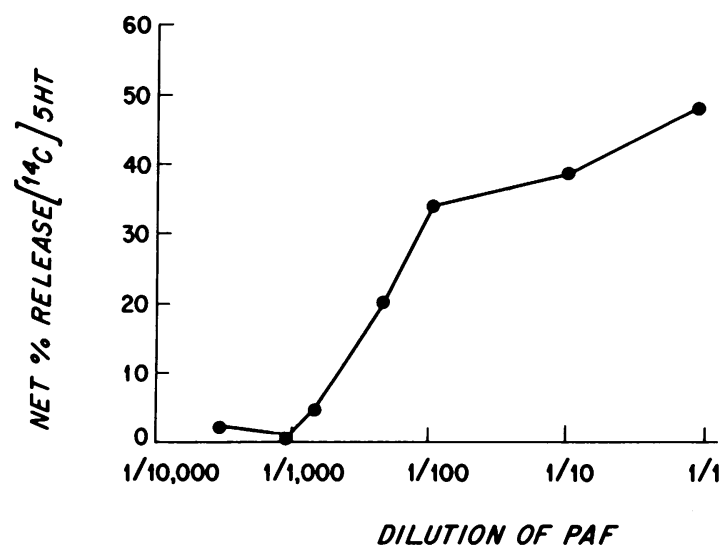

FIGURE 2 Dose-response relationship of silicic acid-purified PAF activity. prepared by addition of the developing reagents and $\mathrm{CHCl}_{3}$ to tubes containing $0.05,0.1$, and $0.2 \mu \mathrm{mol}$ of choline iodide. The optical density of the standard curve and of the experimental mixtures was determined at $365 \mathrm{~nm}$ by setting the reagent blank at zero. The reagent blank was prepared and processed as for the experimental samples with additional buffer replacing the enzyme. $1 U$ of phospholipase D activity was defined as the amount that generated $1 \mu \mathrm{mol}$ of choline in $1 \mathrm{~h}$ at $37^{\circ} \mathrm{C}$.

\section{RESULTS}

Partial purification of human eosinophil phospholipase $D$. Cell preparations enriched for a particular cell type were extracted to determine whether any of the peripheral blood cells contained phospholipase D. The sonicates containing the equivalent of $5 \times 10^{8} / \mathrm{ml}$ for eosinophils, $5 \times 10^{7} / \mathrm{ml}$ for neutrophils and mononuclear cells, $5 \times 10^{\circ}$ for platelets, and $5 \times 10^{11}$ for erythrocytes were centrifuged at $800 \mathrm{~g}$ for $15 \mathrm{~min}$ at room temperature; the supernates were decanted, and $0.1-\mathrm{ml}$ portions were assayed directly and after further dilution for phospholipase $\mathrm{D}$ activity. The undiluted eosinophil extract generated $4.8 \mu \mathrm{mol}$ of choline $/ \mathrm{h}, 1.5$ when diluted so as to be equivalent to $5 \times 10^{7} \mathrm{cells} / \mathrm{ml}$, and 0.2 when further 10 -fold diluted. None of the undiluted extracts from the other cell types demonstrated choline generation; inactivation of PAF was less than $5 \%$ of that achieved with extracts of a comparable number of eosinophils. That the eosinophil is a principal source of phospholipase D in peripheral leukocytes was further documented by determining the relationship in 26 hypereosinophilic subjects between the number of peripheral eosinophils and the capacity of extracts of mixed leukocytes to hydrolyze L- $\alpha$-phosphatidyl choline (Fig. 3 ). There was a correla-

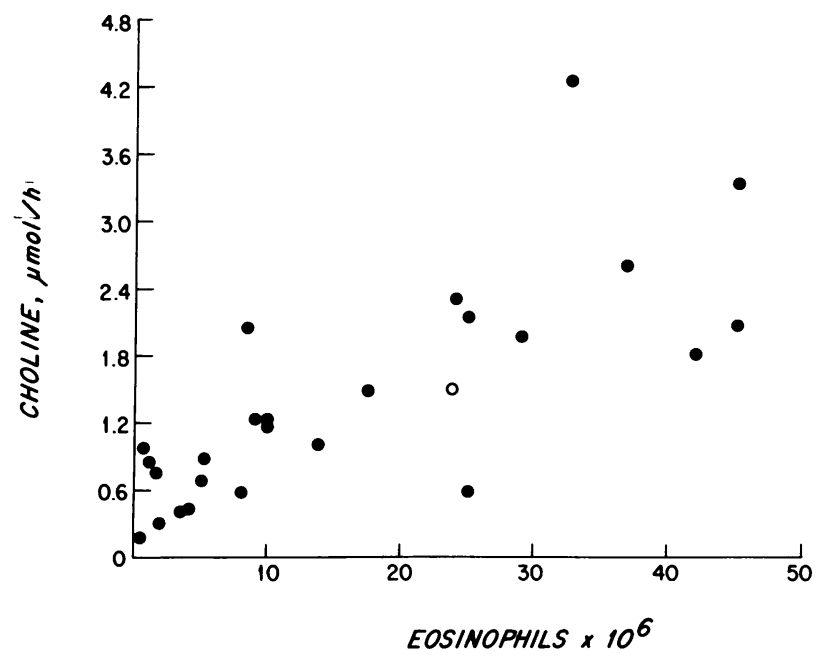

FIgURE 3 Relationship between phospholipase D activity and the number of eosinophils in $1 \mathrm{ml}$ of suspensions of mixed human leukocytes. $O$ denotes the patient from whom the enzyme was purified. 
tion coefficient of 0.65 for the quantity of phospholipase $\mathrm{D}$ and the number of eosinophils per milliliter of mixed leukocytes. The mean phospholipase $\mathrm{D}$ content per $10^{\circ}$ eosinophils for these patients was $0.25 \mathrm{U}$ (range $0.024-$ $0.562 \mathrm{U})$.

A single subject (denoted by the open circle on Fig. 3) with a peripheral leukocyte count ranging from 18,000 to $33,000 / \mathrm{mm}^{3}$ with $80-93 \%$ eosinophilia was utilized as a source of eosinophil phospholipase D for purification. $3 \times 10^{8}$ mixed leukocytes containing $88 \%$ eosinophils were suspended in $3.0 \mathrm{ml}$ Hanks' balanced salt solution, frozen, and thawed three times and sonicated as above. The material was centrifuged at $800 \mathrm{~g}$ for $15 \mathrm{~min}$ at room temperature, and the supernate was dialyzed against two changes of $1,000 \mathrm{ml}$ each $0.1 \mathrm{M}$ Tris- $\mathrm{HCl}$ buffer, $\mathrm{pH} 8.1$, at $4^{\circ} \mathrm{C}$ overnight and applied to a $1.5 \times 25-\mathrm{cm}$ column of DE-52 equilibrated with the same buffer. The column was eluted with two bed volumes of the equilibrating buffer, followed by a linear salt gradient to $0.2 \mathrm{M} \mathrm{NaCl}$ in starting buffer. $100 \mu 1$ portions of each fraction were analyzed for choline-generating and PAF-inactivating activity. The choline-generating and $\mathrm{PAF}$-inactivating activities eluted together at approximately 6-8 mS (Fig. 4). Fractions 113-120 containing both activities were pooled, concentrated to $2 \mathrm{ml}$, and filtered on a $1.5 \times 70-\mathrm{cm}$ Sephadex G-100 column in $0.1 \mathrm{M}$ acetate buffer, $\mathrm{pH}$ 5.5. 100- $\mu$ l portions of each fraction were assayed for choline-generating and PAF-inactivating activities (Fig. 5). Both activities filtered in a single peak at an approximate mol wt of 60,000 . Fractions $40-48$ were concentrated to $2 \mathrm{ml}$ and applied to a $1.5 \times 25-\mathrm{cm}$ column of $\mathrm{CM}-52$ in $0.1 \mathrm{M}$ acetate buffer, $\mathrm{pH}$ 5.5. The column was eluted with two bed volumes of equilibrating buffer followed by a linear salt gradient to $0.3 \mathrm{M} \mathrm{NaCl}$ at a rate of $20 \mathrm{ml} / \mathrm{h}$. $100-\mu 1$ portions of each $4 \mathrm{ml}$ fraction were assayed as above. Both activities appeared only in the effluent, which upon concentration to $2 \mathrm{ml}$ contained $40 \%$ of starting extract activity in a 162-fold purification based upon total protein assessed by a modification of the Folin method (17). The sp act was $156 \mathrm{U} / \mathrm{mg}$, and a comparable sp act of $194 \mathrm{U} / \mathrm{mg}$ was achieved when the isolation procedure was repeated on the cells of the same donor obtained on another occasion. Isoelectric focusing of $10 \mathrm{U}$ of purified phospholipase $\mathrm{D}$ with ampholytes in the range of 3-10 revealed concurrent peaks of cholinegenerating and PAF-inactivating activities which were isoelectric at a $\mathrm{pH}$ of $5.8-6.2$ (Fig. 6). Parallel gels stained for protein showed a band corresponding to the enzyme activity, and four contaminating bands, the closest being at a pI of 5.1 .

The specificity of the phospholipase D and the evidence that a single activity was responsible for the cleavage of phosphatidyl choline was corroborated by thin-layer chromatographic analysis of digestion mixtures. $1 \mathrm{U}$ of phospholipase $\mathrm{D}$ was incubated with 100 $\mu 1$ of $4 \mathrm{mM}$ synthetic dihexanoyl $-\mathrm{L}-\alpha$-lecithin at $25^{\circ} \mathrm{C}$ for 6 or $18 \mathrm{~h}$. Each replicate was extracted with 1 $\mathrm{ml}$ of chloroform, methanol $(2: 1, \mathrm{vol} / \mathrm{vol})$ in two portions, and the organic phase dessicated to $100 \mu 1$ and spotted on silica gel plates. The plates were developed with chloroform: methanol: water $(80: 35: 5$, vol/vol $)$.

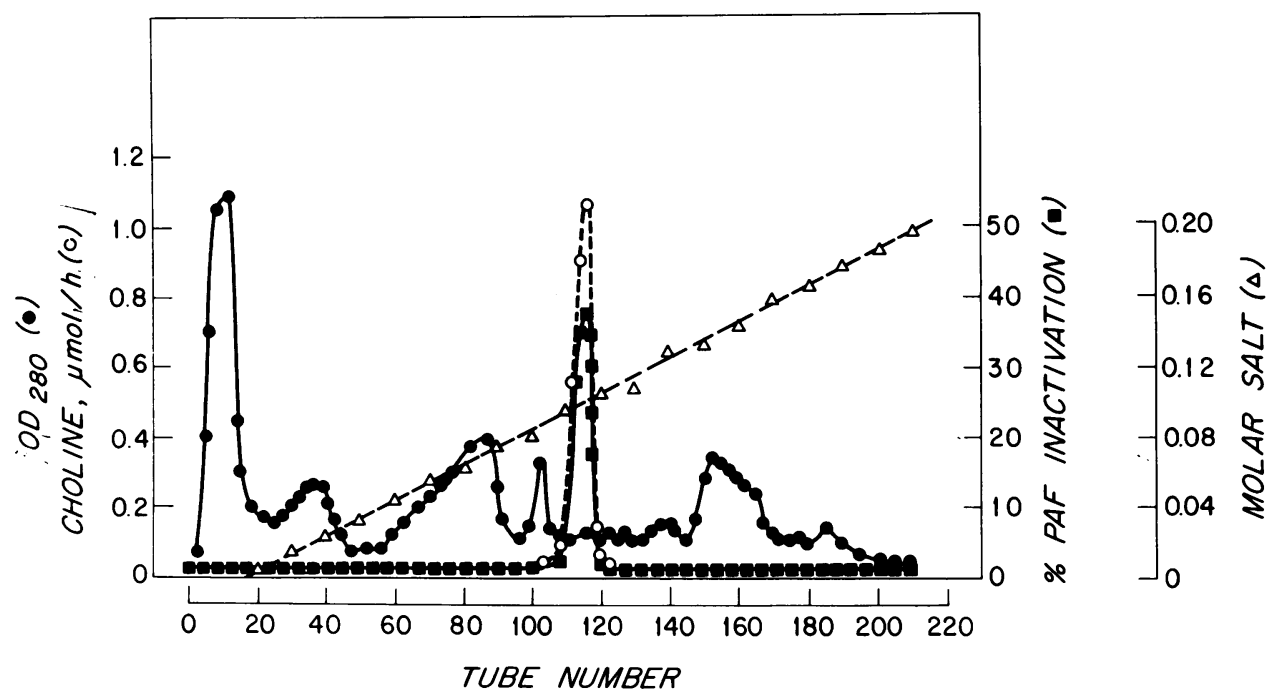

Figure 4 DE-52 chromatography of eosinophil extract. Column bed volume was $44 \mathrm{ml}$, flow rate was $18 \mathrm{ml} / \mathrm{h}$, and fraction volume was $4 \mathrm{ml}$. Choline generation was not plotted for the regions of the chromatogram in which it was not detected. 


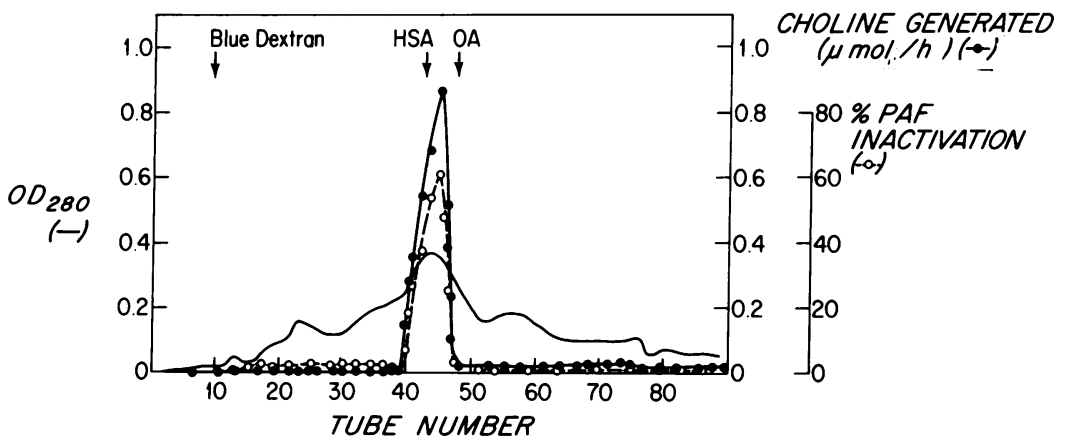

FIgURE 5 G-100 chromatography of eosinophil phospholipase D. Column bed volume was 124 $\mathrm{ml}$, flow rate was $10 \mathrm{ml} / \mathrm{h}$, and fraction volume was $2 \mathrm{ml}$.

The only product detected after spraying with $2^{\prime}, 7^{\prime}$-dichlorofluorescein was phosphatidic acid identified by cochromatography of a purified standard.

The $\mathrm{pH}$ optimum of eosinophil phospholipase $\mathrm{D}$ was defined by interacting $2 \mathrm{U}$ with the standard lecithin substrate concentration in $0.1 \mathrm{M}$ acetate buffer ranging in $\mathrm{pH}$ from 3.5 to 6.0 , and in $0.1 \mathrm{M}$ Tris- $\mathrm{HCl}$ buffer ranging in $\mathrm{pH}$ from 6.5 to 9.5 , at $37^{\circ} \mathrm{C}$ for $1 \mathrm{~h}$. The $\mathrm{pH}$ optimum was 4.5-6.0, compatible with that reported for phospholipase D of cabbage and peanuts (18-20).

$100 \mu \mathrm{l}$ of rat PAF activity purified through silicic acid was incubated with $0.1 \mathrm{ml}$ of $1 \mathrm{mg} / \mathrm{ml}$ pronase, subtilisin, and phospholipases $\mathrm{A}$ and $\mathrm{B}$, in a final volume of $200 \mu 1$ of $\mathrm{SPB}^{++}, \mathrm{pH} 7.2$ at $37^{\circ} \mathrm{C}$ for $2 \mathrm{~h}$. Identical portions of PAF were incubated with limpet arylsulfatase, $10 \mathrm{mg} / \mathrm{ml}$, and cabbage phospholipase $\mathrm{D}, 1 \mathrm{mg} / \mathrm{ml}$, in $0.1 \mathrm{M}$ acetate buffer $\mathrm{pH} 5.5$ for $2 \mathrm{~h}$ at $37^{\circ} \mathrm{C}$. Phospholipase D treatment decreased PAF activity by $40 \%$ whereas the other enzymes failed to diminish its capacity to release $\left[{ }^{14} \mathrm{C}\right]$ serotonin from platelets.
Inactivation of a PAF activity by eosinophil and cabbage phospholipase $D$. Phospholipase D from cabbage source, $250 \mathrm{U}$ in $2.0 \mathrm{ml} 0.1 \mathrm{M}$ acetate, $\mathrm{pH} 5.5$ was filtered on a $1.5 \times 70-\mathrm{cm}$ Sephadex G-100 column equilibrated with the same buffer, and the peak activity was pooled and concentrated to $2.0 \mathrm{ml}, 85 \mathrm{U} / \mathrm{ml}$. Cabbage phospholipase $\mathrm{D}$ filtered just after the front compatible with the published approximate mol wt of 100,000 (18, $20)$ and concentrations of the active fractions revealed $60 \%$ recovery with a sp act of $6.5 \mathrm{U} / \mathrm{mg}$. This preparation was compared with the purified eosinophil phospholipase $\mathrm{D}, 156 \mathrm{U} / \mathrm{mg}$, in terms of the dose-responses for choline generation using the standard substrate concentration, and destruction of PAF employing a $1: 20$ dilution of the usual silicic acid-purified material. The reaction was carried out in $0.1 \mathrm{M}$ acetate buffer, $\mathrm{pH} 5.5$ at $37^{\circ} \mathrm{C}$ for $1 \mathrm{~h}$ in the case of choline generation and $2 \mathrm{~h}$ for PAF inactivation. Choline generation was directly assayed, while the $\mathrm{pH}$ of the reaction mixture containing PAF was adjusted to 7.2 with $1 \mathrm{M}$ sodium acetate and

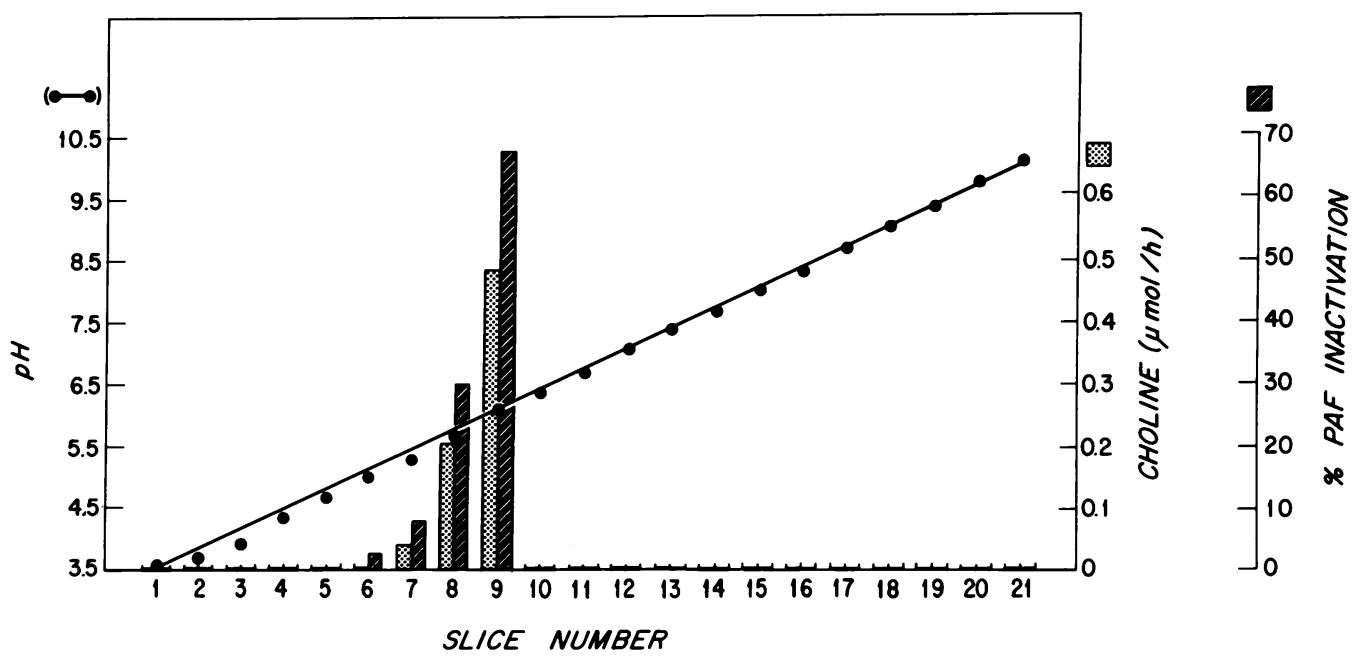

FIGURE 6 Isoelectric focusing of eosinophil phospholipase D. 


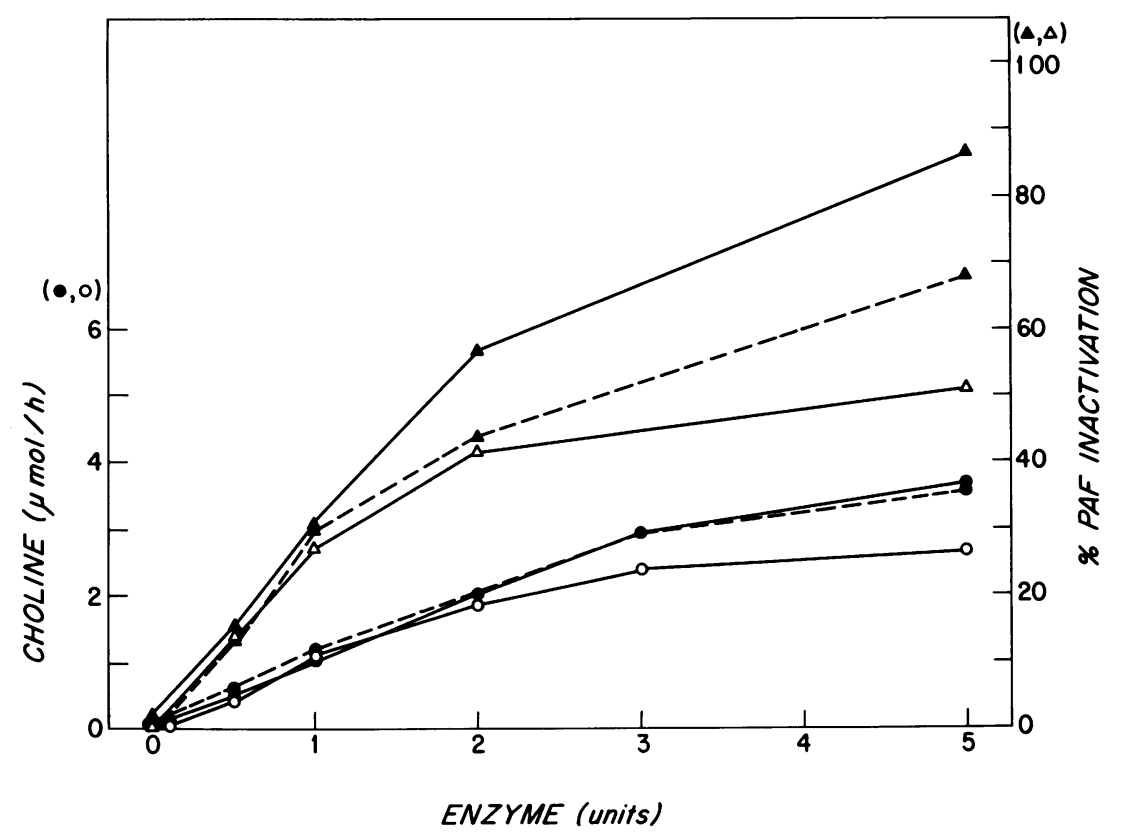

Figurc 7 Dose-response of human eosinophil and cabbage phospholipase D. $\frac{1}{10}-\mathrm{ml}$ samples of Sephadex G-100 filtered cabbage enzyme or CM-52-purified eosinophil enzyme, containing the units of activity indicated on the abscissa, were assayed for choline generation and PAF inactivation as described in the text except that the PAF solution was $1: 20$ and was further diluted to $1: 200$ before assay. Crude eosinophil extract $(O-O, \Delta-\Delta)$; eosinophil phospholipase D purified through CM-52 cellulose ( $-\bullet, \Delta-\Delta)$; and Sephadex G-100 purified cabbage phospholipase D $(\bullet--\bullet, \boldsymbol{\Delta}--\boldsymbol{\Delta})$. Choline-generating activity $(\bullet, \mathrm{O})$; PAF-inactivating activity $(\boldsymbol{\Delta}, \Delta)$.

diluted to $1: 200$ before assay of residual PAF. As shown in Fig. 7, partially purified cabbage phospholipase $\mathrm{D}$ and crude and purified eosinophil phospholipase D yielded a dose-related liberation of choline and inactivation of PAF. At high enzyme concentrations cholinegenerating activity fell below the unit activity values obtained by analysis of diluted samples. The comparable activity of the crude and purified eosinophil phospholipase $\mathrm{D}$ would suggest that the increase in specific ac-

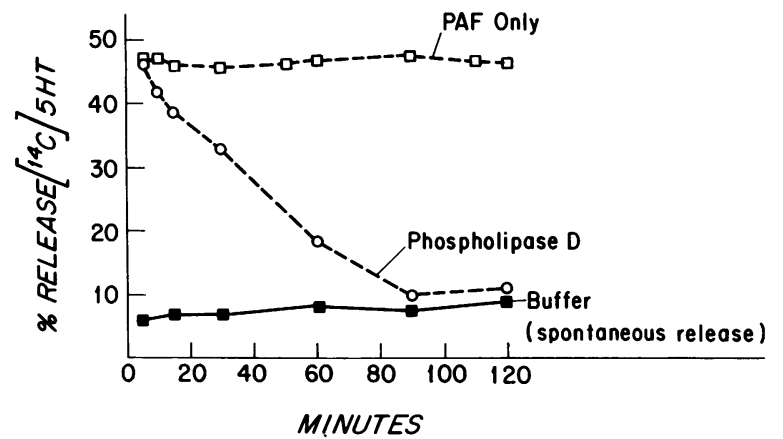

FIgURE 8 Phospholipase D inactivation of PAF. Phospholipase $\mathrm{D}$ incubation performed in $0.1 \mathrm{M}$ acetate $\mathrm{pH} 5.5$, with $5 \mathrm{U}$ of enzyme, at $37^{\circ} \mathrm{C}$ for time intervals shown. tivity during purification was not due principally to removal of an inhibitor.

The time-course of PAF inactivation by purified eosinophil phospholipase $\mathrm{D}$ at a dose of $5 \mathrm{U}$ was examined at $37^{\circ} \mathrm{C}$ as described for the dose-response analysis. PAF inactivation was apparent after $10 \mathrm{~min}$ and complete by $90 \mathrm{~min}$ (Fig. 8). PAF incubated in buffer alone lost no activity during the $2 \mathrm{~h}$ of observation, and $5 \mathrm{U}$ of enzyme incubated in buffer for the same time period had no effect on the platelets.

The effect of varying concentrations of silicic acidpurified PAF on the choline-generating activity of 0.6 $U$ of eosinophil phospholipase $D$ was determined under the standard reaction conditions of $1 \mathrm{~h}$ at $37^{\circ} \mathrm{C}$. The suppression of choline generation was 32,59 , and $68 \%$ with the respective presence of $1: 800,1: 400$, and $1: 200$ dilutions of PAF. In an additional experiment, $0.5 \mathrm{U}$ of purified eosinophil phospholipase $\mathrm{D}$ was incubated with a 1:200 dilution of PAF alone and in the presence of increasing amounts of lecithin for $2 \mathrm{~h}$ at $37^{\circ} \mathrm{C}$. PAF alone yielded $37 \%$ net release of $\left[{ }^{14} \mathrm{C}\right]-$ serotonin. The PAF incubated with enzyme in the absence of lecithin was $85 \%$ inactivated, while $0.1,1$, and $5 \mu \mathrm{mol}$ of lecithin achieved an incremental protection 
such that the residual PAF activity was 12,38 , and $80 \%$ of that incubated in buffer alone.

\section{DISCUSSION}

The unique association of phospholipase D with human polymorphonuclear leukocytes of the eosinophil class is appreciated by the relationship of total extractable phospholipase $\mathrm{D}$ in a mixed cell pool of human leukocytes to its content of eosinophils (Fig. 3). The allocation of phospholipase $\mathrm{D}$ to the eosinophil is corroborated by the extraction of this activity from populations of human leukocytes containing more than $88 \%$ eosinophils, from a single donor on two occasions, and by the absence of such activity from preparations of polymorphonuclear leukocytes, mononuclear leukocytes, platelets, and erythrocytes at comparable cell concentrations. The eosinophil content of phospholipase $\mathrm{D}$ in the donor from whose cells the enzyme was purified was $0.066 \mathrm{U} / 10^{\circ}$ eosinophils which fell in the midregion of the range for levels of 25 other donors of $0.024-0.562 \mathrm{U} / 10^{8}$ eosinophils (Fig. 3 ). The eosinophil phospholipase $D$ chromatographed as a single peak on DE-52 (Fig. 4), Sephadex G-100 (Fig. 5), and CM-52, with an overall recovery of approximately $40 \%$. Isoelectric focusing of the purified enzyme also revealed a single peak of activity, as well as the presence of at least four contaminating proteins without this activity (Fig. 6). Thin-layer chromatographic analysis of digestion mixtures of eosinophil phospholipase D and synthetic lecithin revealed the liberation of phosphatidic acid alone. Taken together, these data would indicate that the eosinophil contains phospholipase $\mathrm{D}$ of restricted physicochemical characteristics.

The eosinophil phospholipase $\mathrm{D}$ exhibited an apparent mol wt of 50,000 (Fig. 5) as compared to the cabbage phospholipase $\mathrm{D}$ which filtered with an apparent mol wt of 100,000 , and phospholipase D from plant sources whose mol wt ranged from 100,000 to $200,000(18-20)$. The $\mathrm{pH}$ optimum of $4.5-6.0$ for the eosinophil phospholipase $\mathrm{D}$ is entirely compatible with that observed for plant phospholipase D obtained from peanut and cabbage $(18,19)$. The pI of partially purified human eosinophil phospholipase $\mathrm{D}$ was 5.8-6.2, while that of the whole eosinophil extract on sucrose gradient columns was 4.8-5.0. The latter is comparable with the value of 4.65 observed for the peanut enzyme (19).

A natural substrate of both eosinophil and cabbage phospholipase D would appear to be a mediator of immediate type hypersensitivity reactions, a PAF activity. The PAF activity was produced in the peritoneal cavities of rats prepared with hyperimmune antiserum rich in IgGa and challenged with specific antigen. The activity was ethanol extracted, separated from water soluble mediators on XAD-2, and recovered from silicic acid chromatography in the fraction previously noted to contain SRS-A (14). In contrast to SRS-A $(21,22)$, the PAF activity was stable to treatment with arylsulfatase B. The capacity of eosinophil phospholipase D, defined by choline liberation from $\mathrm{L}-\alpha$-phosphatidyl choline, to inactivate the PAF activity during sequential purification of the enzyme on DE-52 (Fig. 4), Sephadex G-100 (Fig. 5), and CM-52 is consistent with lecithin and this PAF being substrates of a single protein. This conclusion is supported by the additional finding that both activities focus in a comparable isoelectric region on polyacrylamide gels (Fig. 6). Although only partially purified, phospholipase $\mathrm{D}$ extracted from cabbage also exhibited both activities. The enzymatic nature of the interaction between phospholipase $\mathrm{D}$ and PAF is indicated by the time-dependent inactivation (Fig. 8) and the finding that higher enzyme to substrate ratios achieved greater inactivation in the same time period (Fig. 7). That a single active site is involved in lecithin cleavage and PAF inactivation of a PAF activity was not established, but is consistent with the finding that the presence of one substrate suppressed the cleavage or inactivation of the other.

Phospholipase $\mathrm{D}$ has previously been recognized in mammals only in rat brain (23), and thus its demonstration in human eosinophils represents its initial recognition in primates. Its presence in the eosinophil is particularly noteworthy, since this cell type is directed to the site of immediate type hypersensitivity reactions by specific tetrapeptide chemotactic principles designated eosinophil chemotactic factor of anaphylaxis $(12,24)$. The eosinophil has been previously recognized to contain arylsulfatase B, which inactivates SRS-A (22), and to share with the neutrophil the capacity to inactivate histamine through its content of histaminase (25). The eosinophil is now appreciated to contain also an enzyme capable of destroying an additional mediator with PAF activity. It should be noted however that the PAF activity derived by an IgGa antibody-mediated reaction in the rat need not be identical with that elaborated by other activating reactions involving different cell sources $(4,5,8,9)$.

\section{ACKNOWLEDGMENTS}

This work was supported by grants AI-07722 and AI-10356 from the National Institutes of Health.

\section{REFERENCES}

1. Barbaro, J. F., and N. J. Zvaifler. 1966. Antigen induced histamine release from platelets of rabbits producing homologous PCA antibody. Proc. Soc. Exp. Biol. Med. 122: 1245-1247.

2. Schoenbechler, M. J., and J. F. Barbaro. 1968. The requirement for sensitized lymphocytes in one form of antigen-induced histamine release from rabbit platelets. Proc. Natl. Acad. Sci. U. S. A. 60: 1247-1251. 
3. Siraganian, R. P., and A. G. Osler. 1969. Histamine release from sensitized rabbit leukocytes and associated platelet involvement. J. Allergy. 43: 167. (Abstr.)

4. Siraganian, R. P., and A. G. Osler. 1971. Destruction of rabbit platelets in the allergic response of sensitized leukocytes. I. Demonstration of a fluid phase intermediate. J. Immunol. 106 : 1244-1251.

5. Benveniste, J., P. M. Henson, and C. G. Cochrane. 1972. Leukocyte-dependent histamine release from rabbit platelets. The role of $\operatorname{IgE}$, basophils, and a platelet-activating factor. J. Exp. Med. 136: 1356-1377.

6. Benveniste, J. 1974. Platelet-activating factor, a new mediator of anaphylaxis and immune complex deposition from rabbit and human basophils. Nature (Lond.). 249: $581-582$.

7. Lewis, R. A., E. J. Goetzl, S. I. Wasserman, F. H. Valone, R. H. Rubin, and K. F. Austen. 1975. The release of four mediators of immediate hypersensitivity from human leukemic basophils. J. Immunol. 114: 87-92.

8. Bogart, D. B., and D. J. Stechschulte. 1974. Release of platelet activating factor from human lung. Clin. Res. 22: 652A. (Abstr.)

9. Benveniste, J., P. Kamoun, and J. Polonsky. 1975. Aggregation of human platelets by purified platelet activating factor from human and rabbit basophils. Fed. Proc. 34 : 985 . (Abstr.)

10. Orange, R. P., M. D. Valentine, and K. F. Austen. 1968. Antigen-induced release of (SRS-A ${ }^{\text {rat }}$ ) in rats prepared with homologous antibody. J. Exp. Med. 127 : 767-782.

11. Kater, L. A., K. F. Austen, and E. J. Goetzl. 1975. Identification and partial purification of a platelet activating factor (PAF) from rat. Fed. Proc. 34: 985. (Abstr.)

12. Goetzl, E. J., S. I. Wasserman, and K. F. Austen. 1975. Eosinophil polymorphonuclear leukocyte function in immediate hypersensitivity. Arch. Pathol. 99: 1-4.

13. Valone, F. H., K. F. Austen, and E. J. Goetzl. 1974. Modulation of the random migration of human platelets. J. Clin. Invest. 54 : 1100-1106.

14. Orange, R. P., R. C. Murphy, M. L. Karnovsky, and K. F. Austen. 1973. The physicochemical characteristics and purification of slow-reacting substance of anaphylaxis. J. Immunol. 110: 760-770.
15. Long, C., R. Odavic, and E. J. Sargent. 1967. The action of cabbage-leaf phospholipase $\mathrm{D}$ upon lysolecithin. Biochem. J. 102: 216-220.

16. Böyum, A. 1968. Isolation of leukocytes from human blood, further observations. Methyl cellulose, dextran, and Ficoll as erythrocyte-aggregating agents. Scand. J. Clin. Lab. Invest. 21 (Suppl. 97) : 31-50.

17. Lowry, O. H., N. J. Rosebrough, A. L. Farr, and R. J. Randall. 1951. Protein measurement with the Folin phenol reagent. J. Biol. Chem. 193: 265-275.

18. Yang, S. F., S. Freer, and A. A. Benson. 1967. Transphosphatidylation by phospholipase D. J. Biol. Chem. 242: 477-484

19. Heller, M., N. Mozes, I. Peri (Abramovitz), and E. Maes. 1974. Phospholipase D from peanut seeds. IV. Final purification and some properties of the enzyme. Biochem. Biophys. Acta. 369: 397-410.

20. Dawson, R. M. C., and M. Hemington. 1967. Some properties of purified phospholipase $\mathrm{D}$ and especially the effect of amphipathic substances. Biochem. J. 102: 76-86.

21. Orange, R. P., R. C. Murphy, and K. F. Austen. 1974. Inactivation of slow reacting substance of anaphylaxis (SRS-A) by arylsulfatases. J. Immunol. 113: 316-322.

22. Wasserman, S. I., E. J. Goetzl, and K. F. Austen. 1975. Inactivation of slow reacting substance of anaphylaxis by human eosinophil arylsulfatase. J. Immunol. 114: 645-649.

23. Saito, M., and J. Kanfer. 1975. Phosphatidohydrolase activity in a solubilized preparation from rat brain particulate fractions. Arch. Biochem. Biophys. 169: 318323.

24. Goetzl, E. J., and K. F. Austen. 1975. Purification and synthesis of eosinophilotactic tetrapeptides of human lung tissue: identification as eosinophil chemotactic factor of anaphylaxis (ECF-A). Proc. Natl. Acad. Sci. (U.S. A.). 72: 4123-4127.

25. Zeiger, R., D. Yurdin, and H. Colten. 1976. Histamine metabolism: Cellular and subcellular localization of the catabolic enzymes, histamine and histamine methyl transferase in human leukocytes. J. Allergy Clin. Immunol. In press. 